\title{
AKTIVITAS ANTIOKSIDAN DAN HEPATOPROTEKTOR BATANG MACARANGA TANARIUS SECARA IN VITRO
}

\section{ANTIOXIDANT AND HEPATOPROTECTOR ACTIVITIES OF THE STEMS OF MACARANGA TANARIUS IN VITRO}

\author{
Fikriah I. ${ }^{1}$, Marliana $\mathrm{E}^{2}$ dan Ismail S. ${ }^{1}$ \\ ${ }^{1}$ Laboratorium Farmakologi Fakultas Kedokteran Universitas Mulawarman \\ Jl. Kerayan, Kampus Gunung Kelua, Samarinda \\ ${ }^{2}$ Laboratorium Kimia Organik Jurusan Kimia F-MIPA Universitas Mulawarman \\ JI. Barong Tongkok, Kampus Gunung Kelua, Samarinda \\ Email: Ika_fikriah@yahoo.com
}

Naskah diterima 5 Oktober 2012 , disetujui 22 November 2012

\begin{abstract}
ABSTRAK
Ada hubungan erat aktivitas antioksidan dengan aktivitas hepatoprotektor secara in vitro dan in vivo. Macaranga tanarius (MT) banyak di Kaltim dan ekstrak metanol batangnya diketahui memiliki aktivitas antioksidan, tetapi khasiat ekstrak dan fraksi sebagai hepatoprotektor secara in vitro dan kandungan metabolit sekunder dengan aktivitas antioksidan belum diketahui. Maka penelitian ini bertujuan untuk mengetahui fraksi aktif dari batang $M$. tanarius sebagai antioksidan dan atau hepatoprotektor, serta mengetahui profil kromatogramnya. Prosedur dalam penelitian ini yaitu simplisia MT dimaserasi dengan metanol pada suhu kamar selama 3 hari dan diulang tiga kali. Ekstrak difraksinasi dengan pelarut polaritas yang meningkat dimulai dari $n$-heksan, diklorometan $\left(\mathrm{CH}_{2} \mathrm{Cl}_{2}\right)$, etil asetat (EtOAc), $n$-butanol dan air. Ekstrak kasar dan ke lima fraksi yang didapat diuji aktivitas antioksidan dengan radikal 2,2-diphenyl-1-picrylhidrazyl (DPPH), dan hepatoprotektor secara in vitro. Fraksi paling aktif dibuat profil kromatogram dengan kromatografi lapis tipis silika gel $60 \mathrm{~F}_{254}$. Penelitian ini menunjukkan aktivitas antioksidan paling kuat pada fraksi EtOAc dengan nilai $\mathrm{EC}_{50}(24.06+0.96) \mu \mathrm{g} / \mathrm{mL}$ dan mengandung metabolit sekunder polifenol dengan aktivitas antioksidan. Aktivitas hepatoprotektor in vitro paling kuat pada fraksi EtOAc dengan nilai $\mathrm{EC}_{50}(99 \pm 2) \mu \mathrm{g} / \mathrm{mL}$. Dengan demikian dapat disimpulkan, fraksi EtOAc batang MT memiliki aktivitas antioksidan dan hepatoprotektor secara in vitro dan metabolit sekunder polifenol dengan aktivitas antioksidan.
\end{abstract}

Kata Kunci : Macaranga tanarius, Antioksidan, Hepatoprotektor, Polifenol

\section{ABSTRACT}

There is strong correlation between antioxidant activity and hepatoprotector activities in vitro. Macaranga tanarius (MT) is abundant at East Kalimantan and the stems were proven to have antioxidant activity, but efficacy as hepatoprotector in vitro and active compounds is not known. The aim of this 
research is to examine the active fraction of $M$. tanarius as antioxidant and or hepatoprotector, also it's active compounds. MT simplicia were macerated with methanol at room temperature for 3 days and repeated three times. The extracts were fractionated with increasing solvent polarity starting from n-hexane, dichloromethane, ethyl acetate (EtOAc), n-butanol and water. Crude extract and the five fractions were tested in vitro for antioxidant activity using radical scavenging activity assay using 2,2diphenyl-1-picrylhidrazyl and hepatoprotector activity. Chromatogram profiles were done for the most active fraction using thin-layer chromatography silica gel 60 F254. Results showed the strongest antioxidant activity was EtOAc fraction with $I C_{50}$ values $(6.24 \pm 0.96) \mu \mathrm{g} / \mathrm{mL}$ and contained secondary metabolites polyphenols that proven having antioxidant activity. The strongest in vitro hepatoprotector activity was also EtOAc fraction with $I C_{50}$ values $(99 \pm 2) \mu \mathrm{g} / \mathrm{mL}$. It can be concluded that EtOAc fraction of MT stems had antioxidant and hepatoprotector activity in vitro and contained secondary metabolites polyphenols with antioxidant activity.

\section{Key words : Macaranga tanarius, Antioxidant, Hepatoprotector, Polyphenol}

\section{PENDAHULUAN}

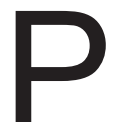

enelitian

hepatoprotektor

kerusakan hat

membutuhkan biaya

Beberapa peneliti

membuktikan uji

hepatoprotektor secara in vitro menggunakan homogenat hati tikus atau mencit berhubungan erat dengan penemuan jenis tumbuhan yang mempunyai aktivitas hepatoprotektor in vivo [Menendez et al., 2000; Gupta et al., 2004], ekstrak tumbuhan atau metabolit sekunder dengan aktivitas antioksidan secara in vitro dengan uji peredaman radikal DPPH dapat beraktivitas hepatoprotektor terhadap kerusakan hati secara in vitro [Donfack et al., 2008; Jingyu et al., 2010].

Salah satu tumbuhan yang potensial untuk diteliti lebih lanjut karena aktivitas antioksidan yang kuat adalah mara atau dalam bahasa latin Macaranga tanarius dari famili Euphorbiaceae yang banyak terdapat di hutan Kaltim dan masih tumbuh secara liar. Ekstrak metanol batang M. tanarius diketahui memiliki aktivitas peredaman radikal DPPH yang lebih kuat jika dibandingkan curcumin dan telah diketahui mengandung metabolit sekunder polifenol dan terpenoid/steroid [Ismail et al, 2008], tetapi masih belum diketahui aktivitas hepatoprotektor secara in vitro, dan fraksi aktif dengan aktivitas antioksidan dan hepatoprotektor. Maka penelitian ini bertujuan untuk mengetahui fraksi aktif dari batang $M$. tanarius sebagai antioksidan dan atau hepatoprotektor, serta mengetahui profil kromatogramnya.

\section{METODE PENELITAN}

\section{Bahan dan Peralatan}

Bahan yang digunakan untuk penelitian ini adalah batang $M$. tanarius, metanol pro analisis (p.a), diklorometan p.a, etil asetat p.a, $n$-butanol p.a, KLT alumunium silica gel F60 F254, pereaksi $\mathrm{DPPH}$, pereaksi dragendorff, pereaksi anisaldehida, pereaksi $\mathrm{FeCl}_{3}$, pereaksi $\mathrm{AlCl}_{3}$, injeksi ketamin, $\mathrm{FeSO}_{4}$. 
Hewan coba dalam penelitian ini adalah mencit putih strain Balb/c, jenis kelamin jantan yang sehat ditandai bulu yang bersih dan bergerak aktif, berat badan 25-35 gram, umur 4-6 bulan dari Laboratorium Farmakologi Fakultas Kedokteran Universitas Mulawarman. Mencit diaklimasi selama satu minggu pada suhu ruangan yang dipertahankan $21-25^{\circ} \mathrm{C}$, siklus pencahayaan 12 jam sinar matahari dan 12 jam gelap, makanan dan minuman ad libitum. Penggunaan hewan uji telah disetujui oleh komisi etik penelitian Fakultas Kedokteran Universitas Mulawarman.

Peralatan yang digunakan adalah shaker, grinding, siever, oven, corong buchner, rotavapor dengan pompa vakum, sprayer, chamber chromatography, chamber photography for Thin Layer Chromatography (TLC), scanner, dissecting set.

\section{Metode}

\section{Pengambilan dan pembuatan simplisia}

Batang M. Tanarius diambil dari hutan sekunder di Km 30 Balikpapan, Kaltim pada bulan Juli 2011 pada saat musim hujan. Jumlah tumbuhan yang diambil adalah 3 pohon dengan lingkar batang 15-19 cm dan pada saat pengambilan sedang berbunga. Identifikasi jenis dibantu ahli taksonomi dari Balai Penelitian Teknologi Perbenihan Samboja, Badan Penelitian dan Pengembangan Kehutanan, Kementerian Kehutanan untuk keabsahan tanaman yang diambil.

Batang disortasi, pencucian dengan air ledeng mengalir sambil disikat sampai semua kotoran bersih, lalu dibilas dengan aquades, ditiriskan selama satu malam. Pengeringan dengan menggunakan lemari pengering yang berisi bohlam pijar 75 watt sebanyak 10 buah dengan suhu dalam lemari $60{ }^{\circ} \mathrm{C}$ selama 10 hari. Batang tumbuhan kemudian dihaluskan dengan menggunakan gergaji mesin. Setelah dihaluskan dilakukan pengeringan lagi dilemari pengering selama 5 hari. Setelah kering dimasukan dalam kantong plastik lalu dimasukan dalam kulkas suhu $-20^{\circ} \mathrm{C}$ sebelum dilakukan penyarian.

\section{Ekstraksi dan fraksinasi}

Sebanyak 650 gram simplisia $M$. tanarius dimaserasi dengan $12 \mathrm{~L}$ metanol (perbandingan simplisia dan pelarut adalah 1:4) pada suhu kamar selama 3 hari, dikocok dengan shaker orbital kecepatan $2 \mathrm{rpm}$ setiap hari selama 10 menit, dipekatkan dengan vakum rotavapor suhu $50^{\circ} \mathrm{C}$, diulang tiga kali. Ekstrak pekat dihitung volumenya. Sebagian ekstrak pekat dikeringkan dalam desikator yang berisi silika gel biru, setelah kering ekstrak ditimbang. Perbandingan tersebut dapat digunakan untuk penghitungan rendemen. Ekstrak kering disimpan dalam kulkas $4{ }^{\circ} \mathrm{C}$ sebelum dilakukan pengujian lebih lanjut. Ekstrak pekat disimpan dalam suhu kamar sebelum dilakukan fraksinasi.

Ekstrak pekat metanol batang $M$. tanarius pekat dipisahkan lebih lanjut secara fraksinasi dengan corong pisah. Ekstrak pekat dilarutkan dengan aquades yang dideonisasi, kemudian difraksinasi dengan pelarut yang polaritasnya semakin meningkat, berturut-turut dengan pelarut $n$-heksan, diklorometan, etil-asetat, $n$-butanol, dan air. Fraksinasi dilakukan berulang-ulang sampai larutan menjadi tidak berwarna. Fase $n$-heksan, diklorometan, etil asetat, $n$-butanol dipekatkan dengan vakum rotavapor suhu $40^{\circ} \mathrm{C}$, sedangan fase air diuapkan dengan cara dimasukan dalam oven $50{ }^{\circ} \mathrm{C}$ selama satu minggu. Fraksifraksi pekat kemudian dikeringkan dalam desikator yang berisi silika gel biru, setelah kering ditimbang dan dicatat beratnya. Fraksi yang telah dikeringkan disimpan dalam refrigerator 
$4^{\circ} \mathrm{C}$ sebelum dilakukan pengujian lebih lanjut.

\section{Uji aktivitas antioksidan dengan metode DPPH}

Ekstrak kasar, fraksi-fraksi diuji aktivitas antioksidan dengan uji DPPH seperti yang dideskripsikan oleh Ding (2011) dengan modifikasi, yaitu ekstrak kasar/fraksi dilarutkan dengan metanol, sebagai pembanding kekuatan aktivitas antioksidan digunakan curcumin dan ekstrak Curcuma xanthorrhiza. Sebanyak $2 \mathrm{~mL}$ dengan berbagai konsentrasi ekstrak kasar/fraksi direaksikan dengan $1 \mathrm{~mL}$ pereaksi radikal DPPH $0.5 \mathrm{~mm}$ selama 15 menit dalam inkubator $37^{\circ} \mathrm{C}$. Perubahan warna dibaca dengan spektrofotometer pada panjang gelombang $517 \mathrm{~nm}$. Penelitian diulang sebanyak tiga kali.

Hasil dinyatakan dalam persen peredaman radikal $\mathrm{DPPH}=$ nilai absorbansi blank yang diberi pereaksi DPPH dikurangi [nilai absorbansi sampel dengan pereaksi DPPH dikurangi nilai absorbansi sampel tanpa pereaksi DPPH] dibagi nilai absorbansi blank yang diberi pereaksi DPPH lalu dikali $100 \%$. Data aktivitas peredaman radikal DPPH yang didapat dikonversikan ke nilai $I_{50}$ DPPH (Inhibitiory concentration $50 \%$ pereaksi $\mathrm{DPPH}$ ) dengan menggunakan program Excel 2003 (untuk memperoleh persamaan regresi). Nilai IC diperoleh dari perpotongan garis antara 50\% aktivitas peredaman radikal DPPH (sumbu y) dengan sumbu konsentrasi (sumbu $\mathrm{x}$ ).

\section{Uji aktivitas hepatoprotektor secara in vitro}

Pada pengujian hepatoprotektor secara in vitro, mencit diambil secara random, setelah mencit dieuthanasia dengan injeksi ketamin, hati diambil untuk dibuat homogenisat hati $10 \%$ dalam larutan buffer fosfat $0.01 \mathrm{mmol} / \mathrm{L}$
$\mathrm{pH} 7.4$ dengan homogeniser Turax 25 lalu disentrifus dengan kecepatan 3000 rpm selama 5 menit, supernatan diambil untuk diuji lebih lanjut. Induksi kerusakan hati menggunakan larutan ferosulfat seperti dideskripsikan Gupta \& Sharma (2010) dengan sedikit modifikasi. Sebanyak $0.5 \mathrm{~mL}$ direaksikan dengan $1 \mathrm{~mL}$ ekstrak kasar/fraksi dengan berbagai konsentrasi selama 10 menit, tambahkan $25 \mu \mathrm{L}$ larutan ferosulfat lalu masukan dalam inkubator pada suhu $37^{\circ} \mathrm{C}$ selama 1 jam, kemudian tambahkan $50 \mu \mathrm{L}$ larutan $\mathrm{BHT}$ 0.5\%. Uji peroksidasi lipid Thiobarbituric Acidreactive Subtances (TBARS) pada homogenisat hati mencit seperti yang dideskripsikan oleh Rajeshwar et al, (2005) dengan modifikasi, yaitu dengan menambahkan pereaksi tiobarbiturat 2 $\mathrm{mL}$, dimasukan kedalam penangas air $95^{\circ} \mathrm{C}$ selama 15 menit, lalu didinginkan dengan air dingin. Setelah dilakukan sentrifus, supernatan diambil dan di spektrofotometer pada panjang gelombang $532 \mathrm{~nm}$. Penelitian diulang tiga kali. Sebagai pembanding kekuatan aktivitas antioksidan digunakan curcumin dan ekstrak Curcuma xanthorrhiza.

Aktivitas hepatoprotektor secara in vitro pada homogenisat hati dinyatakan dalam persen peredaman peroksidasi lipid, yaitu nilai absorbansi homogenisat hati tanpa diberi ekstrak/fraksi potensial yang diberi pereaksi tiobarbiturat dikurangi [nilai absorbansi homogenisat hati yang diberi ekstrak/fraksi dan pereaksi tiobarbiturat] dibagi nilai absorbansi homogenisat hati tanpa diberi ekstrak/fraksi/ yang diberi pereaksi tiobarbiturat lalu dikali 100\%. Data aktivitas hepatotektor secara in vitro pada homogenisat hati yang didapat dikonversikan ke nilai IC peredaman lipid peroksidasi homogenisat hati dengan menggunakan program Excel 2003. 


\section{Eksplorasi kandungan metabolit sekunder}

Fase diam digunakan Kromatografi Lapis Tipis (KLT) alumunium silica gel F60 F254 dan fase gerak kloroform:metanol=7:3. Setelah dikembangkan deteksi metabolit sekunder alkaloid dengan pereaksi Dragendorff, terpenoid/steroid dengan pereaksi anisaldehid, polifenol dengan $\mathrm{FeCl}_{3}$, flavonoid dengan pereaksi $\mathrm{AlCl}_{3}$ [Wagner, 1996]. Aktivitas antioksidan dideteksi dengan menyemprotkan pereaksi radikal DPPH dan aktivitas antioksidan ditunjukkan dengan warna yang lebih pucat [Perez et al., 2003].

\section{Analisis data}

Data aktivitas antioksidan dan hepatoprotektor secara in vitro dinyatakan bentuk nilai mean $+\mathrm{SD}$. lalu dilakukan uji normalitas dan variansi, dilakukan uji anova satu jalur jika syarat terpenuhi, dan dinyatakan berbeda bermakna jika $p<0.05$.

\section{HASIL DAN PEMBAHASAN}

Hasil ekstraksi simplisia $M$. tanarius dengan metanol didapatkan rendemen $1.99 \%$ yaitu perbandingan massa ekstrak dan massa simplisia yang dimaserasi lalu dikalikan 100\%. Rendemen yang diperoleh tergolong rendah karena batang $M$. tanarius berwarna putih kecokelatan, sehingga filtrat yang dihasilkan berwarna cokelat sangat muda. Sebanyak $12.95 \mathrm{~g}$ ekstrak kasar metanol difraksinasi secara bertingkat dengan pelarut yang kepolaran semakin meningkat dalam corong pisah, didapatkan $1.13 \mathrm{~g}$ $(10.11 \%)$ hasil fraksinasi dengan pelarut $n$-heksan, $3.81 \mathrm{~g}$ (34.09\%) hasil fraksinasi dengan diklorometan, $1.56 \mathrm{~g}$ $(13.95 \%)$ hasil fraksinasi dengan etil asetat, $2.85 \mathrm{~g}(25.47 \%)$ hasil fraksinasi dengan $n$-butanol, dan $1.83 \mathrm{~g}(16.37 \%)$ hasil fraksinasi terakhir yaitu air.

\section{Aktivitas Antioksidan dengan Uji Peredaman Radikal DPPH}

Aktivitas antioksidan pada ekstrak metanol dan fraksi-fraksi diketahui dengan uji DPPH dan nilai $\mathrm{IC}_{50}$ dapat dilihat pada Gambar 1. Dari nilai $\mathrm{IC}_{50}$ diketahui fraksi etil asetat memiliki aktivitas antioksidan yang paling kuat dengan nilai IC50 yang paling rendah $(24.06 \pm 0.96) \mu \mathrm{g} / \mathrm{mL}$, kemudian diikuti standar curcumin $(24.28 \pm 0.25) \mu \mathrm{g} / \mathrm{mL}$ $>$ standar ekstrak metanol Curcuma xanthorriza $(63.00 \pm 1.36) \mu \mathrm{g} / \mathrm{mL}>$ fraksi diklorometan $(86.57+2.09) \mu \mathrm{g} / \mathrm{mL}$ $>$ ekstrak kasar metanol $(86.59 \pm 3.01)$ $\mu \mathrm{g} / \mathrm{mL}>$ fraksi $n$-butanol $(115.00 \pm 3.29)$ $\mu \mathrm{g} / \mathrm{mL}>$ fraksi air $(24.06 \pm 0.96) \mu \mathrm{g} / \mathrm{mL}$ dan paling lemah adalah fraksi $n$-heksan $(731.05 \pm 15.25) \mu \mathrm{g} / \mathrm{mL}$

Hasil uji statistik $\mathrm{IC}_{50} \mathrm{DPPH}$ pada lima yang terkuat aktivitas antioksidan dengan menggunakan anova satu jalur didapatkan fraksi etil asetat tidak berbeda bermakna jika dibandingkan dengan standar curcumin $(p=0.999)$, tetapi berbeda bermakna jika dibandingkan dengan Curcuma xanthorriza, fraksi diklorometan dan ekstrak kasar metanol dengan $p<0.001$. 


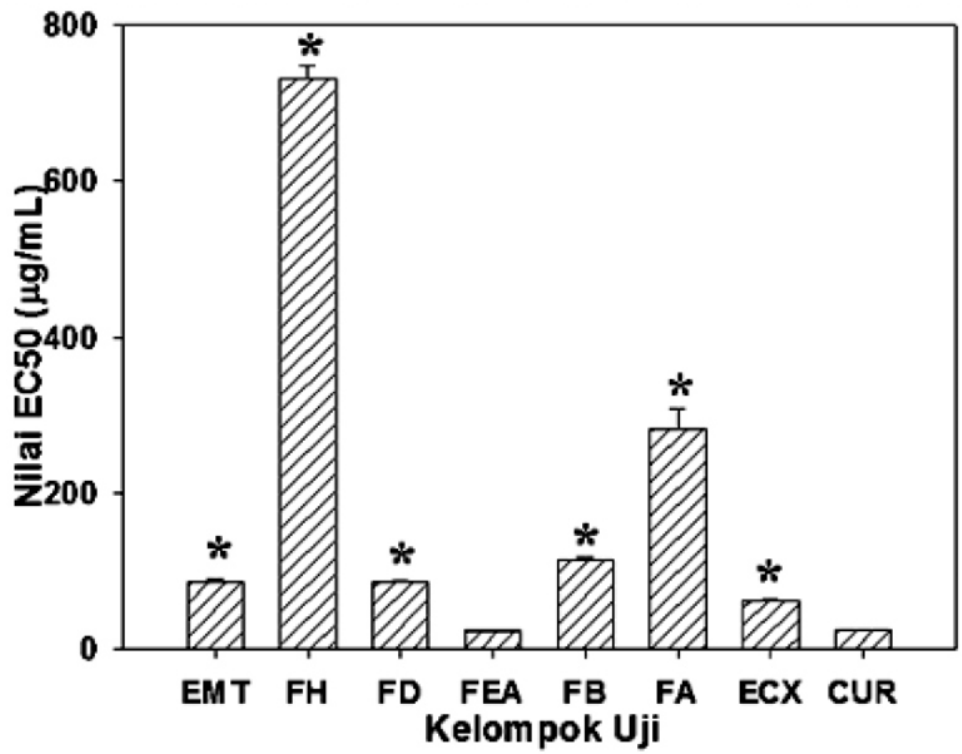

Gambar 1 : Aktivitas Antioksidan Pada Ekstrak Kasar dan Berbagai Fraksi Macaranga tanarius Yang Diuji dengan Radikal DPPH

Keterangan: $n=$ pengulangan tiga kali, EMT=ekstrak metanol $M$. tanarius, $F H=f r a k s i ~ h e k s a n$, $F D=$ fraksi diklorometan, $F E A=$ fraksi etil asetat, $F B=$ fraksi butanol, $F A=$ fraksi air, $E C X=e k s t r a k$ metanol C. xanthorriza, CUR=curcumin. *Uji anova satu jalur berbeda bermakna jika dibandingkan dengan fraksi etil asetat dan curcumin, $p<0.001$

Antioksidan berguna untuk menstabilkan radikal bebas dengan melengkapi kekurangan elektron yang dimiliki radikal bebas, dan menghambat terjadinya reaksi berantai dari pembentukan radikal bebas. Antioksidan adalah senyawa kimia yang memilki kemampuan untuk memberikan hidrogen dan menangkap radikal. DPPH merupakan suatu senyawa radikal bebas yang bersifat stabil dan mampu menerima sebuah elektron atau radikal hidrogen untuk menjadi molekul yang stabil [Molyneux, 2004]. DPPH dapat dengan mudah bereaksi pada semua ikatan tersebut dan DPPH dapat diredam oleh berbagai macam jenis antioksidan, tidak spesifik untuk komponen antioksidan yang khas [Prakash, 2001]. Metode ini cepat, sederhana, dan murah serta digunakan secara luas untuk menguji kekuatan antioksidan pada ekstrak bahan alami. DPPH larut dalam metanol dan memberikan warna ungu, apabila bereaksi dengan senyawa yang dapat memberikan atom hidrogen seperti antioksidan maka DPPH akan menjadi bentuk tereduksi dan mengakibatkan warna larutan memucat menjadi putih kekuningan, penurunan warna ungu menjadi lebih kuning ini menunjukkan korelasi dengan aktivitas antioksidan pada sampel tumbuhan, dan hal ini terlihat seiring dengan peningkatan konsentrasi [Prakash, 2001].

\section{Aktivitas Hepatoprotektor secara in vitro}

Aktivitas hepatoprotektor pada ekstrak metanol dan fraksi-fraksi dapat diketahui dari nilai IC50. Pada Gambar 2 terlihat standar curcumin memiliki aktivitas hepatoprotektor in vitro yang paling kuat dengan nilai IC50 yang paling rendah $(5 \pm 0) \mu \mathrm{g} / \mathrm{mL}$, kemudian diikuti ekstrak Curcuma xanthorriza $(7 \pm$ 0) $\mu \mathrm{g} / \mathrm{mL})>$ fraksi etil asetat $(99 \pm 2)$ $\mu \mathrm{g} / \mathrm{mL}>$ ekstrak kasar metanol $(278 \pm 7)$ $\mu \mathrm{g} / \mathrm{mL}>$ fraksi diklorometan $(291 \pm 6)$ 
$\bigotimes \mathrm{g} / \mathrm{mL}>$ fraksi $n$-heksan $(300 \pm 17)$ $\triangle \mathrm{g} / \mathrm{mL}$ dan yang paling lemah fraksi $n$ butanol $(1,902 \pm 800) \quad \nabla g / m L$, sedangkan fraksi air bersifat merusak hati karena nilai IC50 bernilai negatif yaitu $(-4,210 \pm 2,944) \otimes g / m L$.

Hasil uji statistik IC50 aktivitas hepatoprotektor in vitro pada lima yang terkuat aktivitas antioksidan dengan menggunakan anova satu jalur didapatkan fraksi etil asetat berbeda bermakna jika dibandingkan dengan standar curcumin, Curcuma xanthorriza, ekstrak kasar metanol dan fraksi diklorometan dengan $p<0.001$.

Pada penelitian ini diketahui aktivitas antioksidan pada ekstrak kasar dan fraksi etil asetat batang $M$. tanarius yang diuji dengan metode DPPH dapat digunakan untuk memprediksi khasiat hepatoprotektor secara in vitro. Hasil penelitian ini mempertegas penelitian sebelumnya yang telah membuktikan uji aktivitas hepatoprotektor terhadap kerusakan hati secara in vitro dengan menggunakan homogenat hati tikus atau mencit berhubungan erat dengan penemuan jenis tumbuhan yang mempunyai aktivitas hepatoprotektor in vivo [Menendez et al., 2000; Gupta et al., 2004]. Ekstrak tumbuhan atau metabolit sekunder dengan aktivitas antioksidan secara in vitro yang diketahui dari uji radikal DPPH dapat berkhasiat hepatoprotektor terhadap induksi kerusakan hati secara in vitro [Donfack et al., 2008; Jingyu et al., 2010].

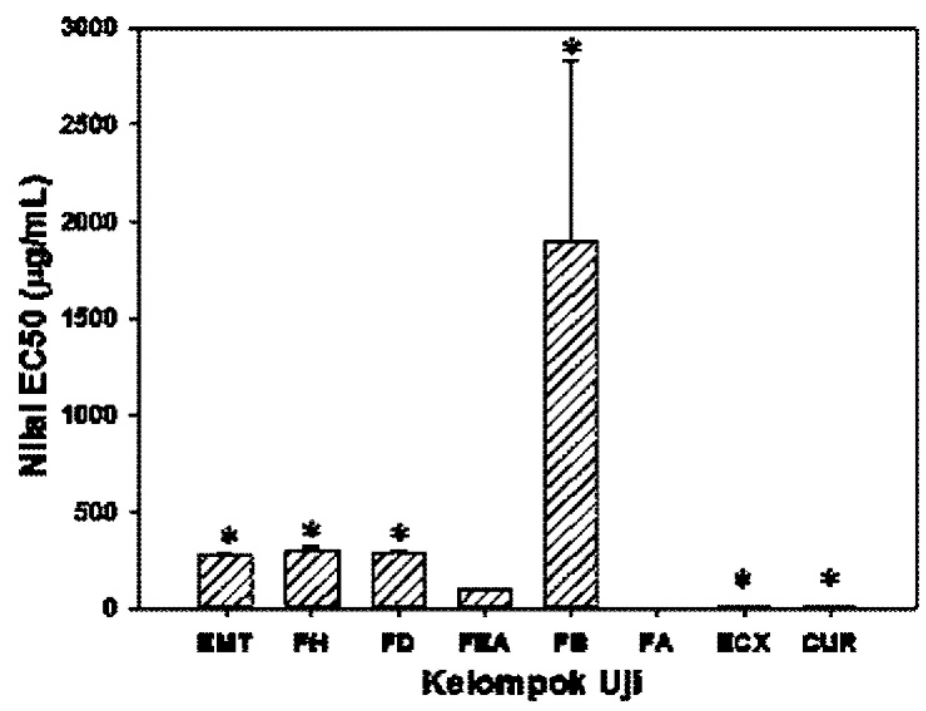

Gambar 2 : Aktivitas Hepatoprotektor In Vitro pada Ekstrak Kasar dan Berbagai Fraksi Macaranga tanarius

Keterangan : $n=$ pengulangan tiga kali, EMT=ekstrak metanol $M$ tanarius, $F H=$ fraksi heksan, $F D=$ fraksi diklorometan, $F E A=$ fraksi etil asetat, $F B=$ fraksi butanol, $F A=$ fraksi air, $E C X=e k s t r a k$ metanol C. xanthorriza, CUR=curcumin.

*Uji anova satu jalur berbeda bermakna jika fraksi etil asetat dibandingkan dengan semua kelompok, $p<0.001$

Aktivitas hepatoprotektor pada penelitian ini kemungkinan besar disebabkan keberadaan metabolit sekunder polifenol dengan aktivitas antioksidan yang telah dibuktikan terdeteksi pada profil kromatogram pada fraksi etil asetat $M$. tanarius. Maka untuk membuktikan diperlukan penelitian isolasi dipandu uji hayati (bioassay guided isolation) untuk mendapatkan 
isolat dengan aktivitas antioksidan dan hepatoprototektor dan dilakukan elusidasi struktur untuk memastikan senyawa aktifnya.

\section{Profil Kromatogram pada Fraksi Aktif}

Pada kromatogram lapis tipis dapat dideteksi metabolit sekunder polifenol dengan aktivitas antioksidan pada nilai $\mathrm{Rf}=0,09$ dan 0,65 . Adanya polifenol ditandai dengan munculnya noktah berwarna hitam setelah plat KLT dispray dengan $\mathrm{FeCl}_{3} 10 \%$. Sedangkan positif antioksidan diketahui dengan munculnya noktah berwarna kuning atau kuning pucat setelah plat KLT dispray dengan DPPH.

Fenolik memiliki kemampuan sebagai antioksidan salah satunya adalah dengan peredaman radikal bebas (free radikal scavenging) karena mampu mentransfer sebuah elektron ke senyawa radikal bebas, dimana $R^{*}$ sebagai senyawa radikal bebas, $\mathrm{FE}-\mathrm{OH}$ sebagai senyawa golongan polifenol [Kandaswami \& Middletton, 1996]

Adanya gugus hidroksil pada senyawa fenolik menyebabkan senyawa fenolik mampu meredam radikal bebas. Fenolik mengamankan sel dari serangan senyawa oksigen reaktif seperti oksigen singlet, superoksida, radikal peroksil, radikal hidroksil dan peroksinitrit [Sirait, 2007].

\section{KESIMPULAN}

Berdasarkan hasil penelitian dapat disimpulkan bahwa fraksi etil asetat batang $M$. tanarius memiliki aktivitas antioksidan dengan nilai IC50 (24.06 \pm 0.96) $\nabla \mathrm{g} / \mathrm{mL}$ dan hepatoprotektor secara in vitro dengan nilai IC50 $(99 \pm 2) \otimes \mathrm{g} / \mathrm{mL}$ serta mengandung metabolit sekunder polifenol dengan aktivitas antioksidan dengan nilai $R f=0,09$ dan 0,65.

\section{UCAPAN TERIMA KASIH}

Pendanaan penelitian ini dari hibah Risbin Iptekdok Badan Penelitian dan Pengembangan Kesehatan Kemenkes RI tahun 2011. Dr. Kade Sidiyasa yang membantu identifikasi jenis. Yunie Safitri S.Si dalam membantu pelaksanaan penelitian di Laboratorium Farmakologi Fakultas Kedokteran Universitas Mulawarman.

\section{DAFTAR PUSTAKA}

Ding HY. 2011. "Extracts and constituents of Rubus chingii with 1, 1-diphenyl-2-picrylhydrazyl (DPPH) free radical scanvenging activity". International Journal of Molecular Switzerland, 12:3941-9.

Donfack JH, Nico FN, Ngameni B, Tchana A, Chuisseu PD, Finzi PV, Ngadjui BT, Moundipa PF. 2008. "In vitro hepatoprotective and antioxidant activities of diprenylated isoflavonoids from Erythrina senegalensis (Fabaceae)". Pharmacology online, 1:382-391.

Gupta M, Mazumder UK, Kumar TS, Gomathi P, Kumar RS. 2004. "Antioxidants and hepatoprotective Effect of Bauhinia racemosa against paracetamol and carbon tetrachloride induced liver damage in rats". Iranian $J$ Pharmacol Therap, 13(1):12-20.

Gupta V and Sharma M. 2010. "Protective effect of Cinnamonum tejpata on lipid peroxide formation in isolated rat liver homogenate". Current Research Journal of Biological Sciences, 2(4):246-249.

Ismail S, Fikriah I, Kosala K, dan Gunawan Y. 2008. "Skrining Fitokimia dan Aktivitas Antioksidan Ekstrak Metanol Batang Macaranga tanarius secara in 
vitro". Laporan Penelitian FKUNMUL (Tidak dipublikasikan).

Jingyu $Y$, Yang $L$, Fang $W$, and Chunfu W. 2010. "Hepatoprotective effects of apple polyphenols on $\mathrm{CCl} 4$ induced acut liver damage in mice". J Agric Food Chem, 58:6525-6531.

Kandaswami, C. and Middleton, E. 1996. "Flavonoids as Antioxidant.

In P. Shahidi (Ed). Natural Antioxidant Chemistry, Health Effects and Applications". Champaign Illinois: AOCS Press.

Menendez R, Amor AM, Gonzales RM, Jimenez S, Mas R. 2000. "Inhibition of rat microsomal lipid peroxidation by the oral administration of D002". Brazillian Journal of Medical and Biological Research, 33:85-90.

Molyneux, P. (2004). "The Use of The Stable Free Radical Diphenylpicryl-hydrazyl (DPPH) for Estimating Antioxidant Activity". Songklanakarin Journal Science Technology, 26(2):211-219.
Perez RM, Vargas R, Martinez FJ, Garcia EV, Hernandez B. 2003. Antioxidant activity of alkaloids from Bocconia arborea: a study on six testing methods. Ars Pharmacetica. 44:5-21.

Prakash, A. (2001). Antioxidant Activity. Medallion Laboratories Analytical Progress. Vol. 19 No. 2. Summer 2001. Pp. 1-6.

Rajeshwar Y, Gupta M, and Mazumder UK. 2005. "In Vitro lípido peroxidation and antimikrobial activity of Mucuna pruriens seeds". Iranian Journal of Pharmacology \& Therapeutics, 4:32-35.

Sirait, M. 2007. Penuntun Fitokimia Dalam Farmasi. Bandung: ITB Press.

Wagner, H. and Bladt, S. 2006. Plant Drug Analysis: A Thin Layer Chromatography Atlas. Second Edition. Germany: Springer. 